\title{
KECERNAAN SERAT BERBAGAI JENIS PAKAN PRODUK SAMPING PERTANIAN (BY PRODUCT) SEBAGAI PAKAN TERNAK RUMINANSIA YANG DI UJI SECARA IN VITRO
}

\author{
FIBER DIGESTIBILITY OF VARIOUS TYPES OF BY PRODUCT AS RUMINANT FEED \\ TESTED BY IN VITRO
}

\author{
Siti Athiya Wibowo*1, Marry Christiyanto1, Limbang Kustiawan Nuswantara1, \\ dan Eko Pangestu', \\ Ilmu Nutrisi dan Pakan Fakultas Peternakan dan Pertanian, Universitas Diponegoro, \\ J1. Prof. H. Soedarto, S.H - Tembalang Semarang, Indonesia 50275 \\ *Corresponding author : sitiathiyawibowo97@gmail.com \\ Diterima: 21 Juni 2019, Direvisi: 15 Nopember 2019, Disetujui: 9 Desember 2019
}

\begin{abstract}
ABSTRAK
Penelitian ini bertujuan untuk mengkaji kecernaan serat bahan pakan hasil samping pertanian sebagai pakan alternatif pengganti hijauan untuk ternak ruminansia. Penelitian dilakukan dengan metode in vitro menggunakan cairan rumen kambing Peranakan Etawa (PE). Rancangan percobaan yang digunakan adalah rancangan acak lengkap (RAL) dengan 6 jenis bahan pakan (kulit kacang, kulit kopi, kulit pisang, sabut kelapa, onggok dan janggel jagung) dengan 3 ulangan. Hasil penelitian menunjukkan bahwa perlakuan berbagai macam bahan pakan berpengaruh nyata $(\mathrm{P}<0,05)$ terhadap kecernaan bahan kering, kecernaan Neutral Detergent Fiber (NDF), kecernaan Acid Detergent Fiber (ADF) dan kecernaan Hemiselulosa. Kecernaan bahan kering dan kecernaan NDF menunjukkan bahwa onggok dan janggel jagung memiliki kecernaan yang paling baik, kecernaan ADF menunjukkan bahwa onggok, janggel jagung dan kulit kopi memiliki kecernaan yang paling baik dan kecernaan hemiselulosa menunjukkan onggok, janggel jagung dan kulit pisang memiliki kecernaan yang paling baik. Onggok, janggel jagung, kulit kopi dan kulit pisang memiliki kecernaan serat yang baik dan dapat dimanfaatkan sebagai pengganti pakan hijauan untuk pemenuhan kebutuhan ruminansia.
\end{abstract}

Kata kunci: ADF, by product, Hemiselulosa dan NDF

\section{ABSTRACT}

The aim of this study was to examine the digestibility of fiber from agricultural by products as an alternative feed forage for ruminant. The study was conducted by in vitro method with PE goat rumen fluid. The experimental design used was a completely randomized design (CRD) with 6 types of feed ingredients (peanut hull, coffee hull, banana peels, coconut fiber, cassava wastelonggok and corncake) with 3 replications. The results showed that the treatment of various kinds of feed ingredients significantly affected $(P<0.05)$ the digestibility of dry matter, neutral detergent fiber $(N D F)$, acid detergent fiber $(A D F)$ and hemicellulose. Onggok and corncake had the best DM and NDF digestibility. Onggok, corncake and coffee hull had the best ADF digestibility. Onggok, corncake and banana peel had the best hemicellulose digestibility. Onggok, corncake, coffee hill and banana peel had good fiber digestibility and can be used as a substitute for forage to meet ruminant requirement.

Keywords; ADF, By product, Hemisellulose and NDF

Kecernaan Serat Berbagai Jenis Pakan Produk Samping Pertanian (By Product) sebagai Pakan Ternak 


\section{PENDAHULUAN}

Pakan ruminansia sebagian besar dipenuhi dari hijauan. Pakan yang berserat merupakan bahan bahan yang banyak terdapat pada tanaman pakan (Christiyanto dan Subrata, 2005). Pertumbuhan populasi ruminansia semakin meningkat, maka kebutuhan pakan juga semakin meningkat, namun lahan hijauan pakan makin tersisih oleh pemanfaatan lahan untuk pertanian termasuk perkebunan, maupun untuk keperluan non-pertanian, sehingga sumber penyediaan pakan hijauan menjadi terbatas (Mathius dan Sinurat, 2001). Pakan by product menjadi suatu alternatif karena memiliki potensi berupa kandungan nutrien seperti protein dan energi, kompoisi kimia pakan by product dapat dilihat pada Tabel 1.

Tabel 1.

Kandungan Nutrisi dan Komponen Serat Bahan Pakan By Product

\begin{tabular}{lrrrrrr}
\hline & \multicolumn{7}{c}{ PERLAKUAN } \\
\cline { 2 - 7 } parameter & \multicolumn{1}{c}{ T1 } & \multicolumn{1}{c}{ T2 } & \multicolumn{1}{c}{ T3 } & \multicolumn{1}{c}{ T4 } & \multicolumn{1}{c}{ T5 } & \multicolumn{1}{c}{ T6 } \\
\cline { 2 - 7 } & Onggok & k. pisang & \multicolumn{1}{c}{ J. } & \multicolumn{1}{c}{ K. } & \multicolumn{1}{c}{ S. } & \multicolumn{1}{c}{ K. } \\
& 88,56 & 87,07 & 89,83 & 92,35 & 86,59 & 88,02 \\
Bahan Kering & 95,86 & 86,58 & 95,64 & 96,64 & 91,11 & 94,09 \\
Bahan Organik & 0,26 & 8,39 & 4,77 & 3,19 & 2,47 & 1,51 \\
Lemak Kasar & 5,92 & 6,33 & 6,96 & 10,28 & 6,91 & 8,23 \\
Protein Kasar & 8,25 & 30,92 & 43,04 & 50,89 & 62,11 & 68,72 \\
Serat Kasar & 81,42 & 40,94 & 40,86 & 32,27 & 19,62 & 15,64 \\
BETN & 55,88 & 35,63 & 53,62 & 65,21 & 66,48 & 81,26 \\
NDF & 21,00 & 28,75 & 32,20 & 34,26 & 55,80 & 72,98 \\
ADF & 34,88 & 6,88 & 21,43 & 29,96 & 10,67 & 8,28 \\
Hemisellulosa & 10,51 & 14,22 & 20,92 & 18,19 & 25,63 & 47,40 \\
Selulosa & 10,49 & 14,53 & 11,28 & 16,07 & 30,18 & 25,58 \\
Lignin & 0,70 & 4,66 & 0,50 & 1,85 & 8,13 & 6,47 \\
Silika & 4,14 & 13,42 & 4,37 & 3,37 & 8,89 & 5,91 \\
Abu & 2,00 & 1,98 & 2,85 & 2,13 & 1,85 & 2,85 \\
Rasio ADF/Ligin & 5,33 & 2,45 & 4,75 & 4,06 & 2,20 & 3,18 \\
Rasio NDF/Lignin & & & & & & \\
Rasio & 333 & 0,47 & 1,90 & 1,86 & 0,35 & 0,32 \\
Hemiselulosa/Lignin & 1,00 & 0,98 & 1,85 & 1,13 & 0,85 & 1,85 \\
Rasio Selulosa/Lignin & & & & & & \\
\hline
\end{tabular}

Pakan by product juga memiliki harga yang cukup terjangkau dan mudah untuk didapatkan. Penggunaan pakan by product sebagai alternatif pakan ruminansia dapat menjadi salah satu solusi terhadap kekurangan pakan serta mendorong perkembangan agribisnis ruminansia yang terpadu (Sumadi et al., 2010). Ketersediaan bahan pakan by product cukup terjamin karena produksi tanaman penghasil pakan tersebut cekup tinggi, berdasarakan data di Badan Pusat Statistik (BPS) pada tahun 2015, produksi nasional singkong sebesar 21 Juta ton, produksi pisang sebesar 7 juta ton, produksi jagung sebesar 19 juta ton, produksi kopi sebesar 32 ribu ton, produksi kelapa sebesar 129 ribu ton dan produksi kacang tanah sebesar 600 ribu ton. Produksi pertanian yang tinggi 
tersebut menghasilkan hasil samping yang cukup banyak sehingga ketersediaan bahan pakan tersebut cukup melimpah..

Kambing PE merupakan ternak dengan pencernaan yang dibantu oleh mikroorganisme di dalam rumen, mikrorganisme tersebut berfungsi merombak serat pakan menjadi Volatile Fatty Acids (VFA) (Anggorodi, 1984). Kandungan serat pada pakan akan dimanfaatkan oleh mikroorganisme di dalam rumen seperti bakteri selulolitik untuk di degradasi sehingga menghasilkan energi untuk ternak (Zain, 2007). Bakteri selulitik memiliki beragam jenis dengan masing-masing substrat, seperti Clostridium cellulovorans yang mampu mensintetis enzim hemiselulolitik dan Clostridium acetobutylicum yang menghasilkan enzim selulase (Meryandini et al., 2009). Kecernaan serat setiap bahan pakan memiliki nilai yang berbeda, sehingga sumbangan energi masingmasing pakan terhadap ternak juga berbeda. Perbedaan kecernaan serat bahan pakan tersebut dipengaruhi oleh zat antinutrisi dan kandungan nutrien pakan seperti dinding sel yang merupakan penyangga tubuh tanaman yang mengandung komponen seperti lignin, selulosa, ikatan lignin dengan selulosa dan hemiselulosa yang kuat, sehingga dapat menghambat proses degradasi di dalam rumen (Zakariah et al., 2016).

\section{MATERI DAN METODE PENELITIAN}

Penelitian dilaksanakan pada September 2018 - Januari 2019 di Laboratorium Ilmu Nutrisi dan Pakan, Fakultas Peternakan dan Pertanian, Universitas Diponegoro, Semarang. Penelitian menggunakan cairan rumen yang diambil dari kambing PE berfistula di Fakutas Peternakan dan Pertanian, Universitas Diponegoro, Semarang. Bahan pakan by product (kulit kacang, kulit kopi, kulit pisang, sabut kelapa, onggok dan janggel jagung) diambil dari berbagai daerah di Jawa Tengah. Alat yang digunakan yaitu seperangkat alat In vitro, seperangkat alat analisis proximat dan seperangkan alat analisis fraksi serat dengan metode Van Soest (1994).

\section{Tahap Penelitian}

Kambing PE berfistula diberi pakan kontrol. Bahan pakan perlakuan yaitu kulit kacang, kulit kopi, kulit pisang, sabut kelapa, onggok dan janggel jagung dan disamakan ukuran partikelnya dengan pengayakan. Pakan terlebih dahulu dilakukan analisis proksimat dan analisis fraksi serat

Pencernaan in vitro dilakukan dengan metode Tilley dan Terry (1963) dengan dua tahap pencernaan yaitu penceernaan fermentatif secara anaerob dan pencernaan secara enzimatis dengan pepsin $\mathrm{HCl}$.

Analisis yang dilakukan untuk menghitung kecernaan bahan kering, ADF, NDF dan hemiselulosa yang digunakan residu pakan yang telah dilakukan pencernaan secara in vitro. Analisis kecernaan ADF, NDF dan hemiselulosa menggunakan prosedur Van Soest (1994).

Data yang diperoleh pada penelitian ini dianalisis dengan analisis sidik ragam (Analysis of Variance / ANOVA) menggunakan rancangan acak lengkap (RAL). Uji lanjut menggunakan Duncan's Multiple Range Test (DMRT).

\section{HASIL DAN PEMBAHASAN}

Berdasarkan penelitian yang telah dilakukan, nilai rataan hasil kecernaan bahan kering (KcBK), kecernaan neutral detergent fiber (Kc NDF), kecernaan acids detergent fiber (Kc ADF) dan kecernaan hemiselulosa ditampilkan pada Tabel 2 
Tabel 2.

Rataan nilai kecernaan bahan kering, kecernaan NDF, kecernaan ADF dan kecernaan hemiselulosa.

\begin{tabular}{|c|c|c|c|c|c|c|}
\hline \multirow{3}{*}{ Variabel } & \multicolumn{6}{|c|}{ Bahan Pakan } \\
\hline & $---\cdot$ & --------. & ----\% & -----. & ------. & ----- \\
\hline & Onggok & $\begin{array}{c}\text { Kulit } \\
\text { pisang }\end{array}$ & $\begin{array}{l}\text { Janggel } \\
\text { jagung }\end{array}$ & $\begin{array}{l}\text { Kulit } \\
\text { kopi }\end{array}$ & $\begin{array}{l}\text { Sabut } \\
\text { kelapa }\end{array}$ & $\begin{array}{c}\text { Kulit } \\
\text { kacang }\end{array}$ \\
\hline Kec. BK & $71,97^{\mathrm{a}}$ & $47,60^{\mathrm{b}}$ & $69,17^{\mathrm{a}}$ & $17,86^{\mathrm{d}}$ & $33,35^{\mathrm{c}}$ & $16,44^{\mathrm{d}}$ \\
\hline Kec. NDF & $75,53^{\mathrm{a}}$ & $46,72^{b}$ & $72,42^{\mathrm{a}}$ & $29,80^{c}$ & $41,06^{\mathrm{b}}$ & $32,13^{\mathrm{c}}$ \\
\hline Kec. ADF & $76,73^{\mathrm{a}}$ & $24,90^{\text {cd }}$ & $60,60^{\mathrm{ab}}$ & $56,30^{\mathrm{b}}$ & $32,40^{\mathrm{c}}$ & $18,71^{\mathrm{d}}$ \\
\hline Kec. Hemisellulosa & $74,01^{\mathrm{a}}$ & $65,34^{\mathrm{b}}$ & $68,90^{\mathrm{ab}}$ & $41,00^{\mathrm{c}}$ & $39,61^{\mathrm{c}}$ & $26,78^{\mathrm{d}}$ \\
\hline
\end{tabular}

Superskrip yang berbeda pada baris rata menunjukan perbedaan nyata $(\mathrm{p}<0.05)$.

\section{Kecernaan Bahan Kering (KcBK)}

Hasil analisis ragam kecernaan bahan kering $(\mathrm{KcBK})$ bahan pakan by product yang disajikan pada Tabel 2 menunjukkan bahwa nilai KcBK onggok dan janggel jagung memiliki nilai yang paling baik. Kecernaan bahan kering pada onggok dan janggel jagung yang tinggi dipengaruhi oleh kandungan nutrisi bahan pakan yang tinggi serta terdapat pengaruh dari mikroorganisme di dalam rumen dan kandungan serat pakan. Christiyanto et al. (2005) menjelaskan bahwa kandungan serat (NDF dan ADF) dalam bahan pakan memiliki korelasi negatif dengan kecernaan pakan. Prastyawan et al. (2012) menyatakan bahwa kecernaan suatu bahan pakan dapat dipengaruhi oleh berbagai faktor seperti kandungan kimia atau fisik bahan pakan maupun faktor dari ternak itu sendiri seperti kandungan dan kondisi mikroba dalam rumen. Wijayanti et al. (2012) menyatakan bahwa kandungan serat kasar pada pakan yang rendah pada umumnya pakan akan mudah dicerna oleh mikroba rumen, karena dinding serat rendah maka dinding sel tanaman lebih tipis dan mudah ditembus oleh mikroba di dalam rumen. Kulit kopi dan kulit kacang memiliki kecernaan yang rendah, selain faktor tanaman dan mikroba rumen, juga dapat disebabkan oleh kandungan antinutrisi pada bahan pakan tersebut.
Koten (2010) menyatakan bahwa zat anti nutrisi mampu menurunkan daya cerna pakan seperti protein kalsium dan mineral lainya.

\section{Kecernaan netral detergent fibre (NDF)}

Hasil analisis ragam kecernaan NDF yang ditampilkan pada Tabel 2 menunjukkan bahwa onggok dan janggel jagung memiliki kecernaan NDF yang baik. Hal ini dapat disebabkan oleh kandungan hemiselulosa yang cukup tinggi Tingginya kandungan hemiselulosa pada pakan tersebut dapat meningkatkan kecernaan NDF karena hemiselulosa merupakan bagian dari serat NDF yang dapat dicerna. Hal ini sesuai dengan pendapat Purbajanti et al. (2011) yang menyatakan bahwa hemiselulosa merupakan fraksi serat yang dapat didegradasi oleh mikroba dan dimanfaatkan sebagai sumber energi. Kulit kacang dan kulit kopi memiliki kandungan NDF yang tinggi namun memiliki kecernaan yang rendah. Kecernaan NDF kulit kacang yang rendah dapat disebabkan oleh rasio hemiselulosa terhadap lignin pada kulit kacang yang rendah. Kandungan hemiselulosa yang rendah dan lignin yang tinggi pada pakan dapat membentuk ikatan lignohemiselulosa yang dapat menghambat kecernaan serat oleh mikroba didalam rumen. Menurut Handayani et al. (2018) 
hemiselulosa dan lignin dapat membentuk ikatan yang kuat disebut dengan ikatan lignohemiselulosa, ikatan tersebut dapat menyebabkan bahan pakan sulit untuk dicerna. Imsya dan Palupi (2008) menyatakan bahwa ikatan lignohemiselulosa pada pakan dapat menyebabkan terlinduginya hemiselulosa dari degradasi di dalam rumen. Kulit kopi dan kulit kacang memiliki kecernaan yang rendah dapat disebabkan karena kandungan antinutrisi dan fisiologis tanaman, dimana proses lignifikasi pada pakan yang berasal dari kulit biji-bijian lebih kuat apabila dibandingkan dengan pakan yang berasal dari hijauan. Fachry et al. (2013) menyatakan bahwa lignifikasi pada tanaman terjadi pada tanaman yang mengayu seperti biji tanaman, kulit keras, akar dan batang tanaman.

\section{Kecernaan acid detergent fibre (ADF)}

Hasil analisis ragam menunjukan bahwa nilai kecernaan ADF (Tabel 2.) onggok, janggel jagung dan kulit kopi memiliki nilai kecernan yang baik. Tingginya kecernaan ADF pada pakan tersebut dapat disebabkan oleh rasio kandungan selulosa terhadap lignin yang cukup tinggi, tinginya rasio selulosa terhadap lignin dapat diartikan bahwa pakan tersebut memiliki selulosa yang tinggi namun lignin yang rendah, Selulosa merupakan komponen yang dapat didegradasi oleh enzim selulase. Hal ini sesuai dengan pendapat Meryandini et al. (2009) yang menyatakan bahwa enzim selulotlitik akan memotong ikatan glukosa pada selulosa sehingga selulosa mudah untuk dicerna. Kandungan lignin yang tinggi dapat berikatan dengan selulosa dan membentuk lignoselulosa. Handayani et al. (2018) menyatakan bahwa kandungan lignin dalam pakan dapat berikatan dengan selulosa membentuk ikatan lignoselulosa yang kuat dan sangat sulit untuk di degradasi oleh mikroba rumen. Menurut
Fachry et al. (2013) ikatan lignoselulosa merupakan ikatan yang sangat kuat karena lignin yang melindungi selulosa bersifat tahan terhadap hidrolisis karena memiliki ikatan arialkil dan ikatan eter

\section{Kecernaan Hemiselulosa}

Berdasarkan analisis ragam menunjukan bahwa kecernaan hemiselulosa onggok, janggel jagung dan kulit pisang yang ditunjukkan pada Tabel 2 memiliki nilai kecernaan yang baik. Tingginya nilai kecernaan pakan dapat disebabkan oleh kandungan hemiselulosa yang tinggi dan lignin yang rendah, kandungan hemiselulosa yang tinggi dapat meningkatkan nilai kecernaan hemiselulosa. Hal ini sesuai dengan pendapat Maynard dan Loosli (1969) yang menyatakan bahwa hemiselulosa merupakan komponen yang terbentuk dari monosaarida yang dapat menghasilkan energi untuk ternak. Kulit pisang memiliki kecernaan hemiselulosa cukup tinggi walaupun kulit pisang memiliki kandungan hemiselulosa yang rendah. Kandunan lignin pada kulit pisang juga cukup tinggi, tingginya kandungan lignin dapat mengambat kecernaan bahan pakan. Tillman et al. (1991) menyatakan bahwa lignin merupakan senyawa pembentuk dinding sel tanaman yang akan menurunkan kecernaan pada pakan tersebut.

Tingginya nilai kecernaan hemiselulosa kulit pisang dapat disebabkan komponen gula penyusun hemiselulosa kulit pisang sesuai dengan ketersediaan mikroba pencernanya didalam rumen. Perbedaan nilai kecernaan hemiselulosa bahan pakan dipengaruhi oleh banyak faktor seperti jenis mikoba rumen dan komponen penyusun hemiselulosa yang berbeda antara bahan pakan satu dengan yang lainya sehingga hemiselulosa akan memiliki kecernan yang berbeda sesuai gula penyusun 
hemiselulosa masing bahan pakan. Hal ini sesuai dengan pendapat Sari et al. (2019) bahwa hemiselulosa merupakan polisakaraida yang tersusun dari banyak monomer glukosa sepert xylosa, arabinosa, glukosa, manosa, galaktosa dan monomer D-glukosa lainya yang memiliki bakteri pencerna yang berbeda beda.

\section{KESIMPULAN}

Berdasarkan hasil penelitian dapat disimpulkan bahwa onggok, janggel jagung, kulit kopi dan kulit pisang memiliki kecernaan serat yang baik dan dapat dimanfaatkan sebagai pengganti pakan hijauan untuk pemenuhan kebutuhan ruminansia.

\section{SARAN}

Berdasarkan penelitian yang telah dilakukan perbedaan kecernaan hemiselulosa memiliki nilai yang berbeda antara bahan pakan satu dengan yang lainya, perbedaan nilai kecernaan dapat dipengaruhi oleh monosakarida penyusun hemiselulosa yang berbeda. Penelitian selanjutnya dapat dilakukan penentuan monosakarida penyusun masing-masing bahan pakan sehingga dapat diketahui pengaruh masing-masing komponen terhadap kecernaan hemiselulosa bahan pakan tersebut. 
DAFTAR PUSTAKA

Anggorodi, R., (1994). Ilmu Makanan Ternak Umum. Gramedia Pustaka Utama, Jakarta.

Badan Pusat Statistik Jakarta Pusat. (2015). Statistik Tanaman Pangan Tahun 2015. Badan Pusat Statistik, Jakarta.

Christiyanto, M. dan A. Subrata. 2005. Perlakuan Fisik dan Biologis pada Limbah Industri Pertanian terhadap Komposisi Serat. Laporan Hasil Penelitian. Lemlit UNDIP. Semarang.

Christiyanto, M., M. Soejono, R. Utomo, H. Hartadi, dan B.P. Widyobroto. 2005. Konsumsi dan kecernaan nutrien ransum yang berbeda prekursor protein - energi dengan pakan basal rumput raja pada sapi perah. J. Indon. Trop. Anim. Agric. 30 (4) Desember 2005.

Fachry, A.R., P. Astutik dan T.G. Puspitasari. (2013). Pembuatan bietanol dari limbah tongkol jagung dengan variasi konsentrasi asam klorida dan waktu fermentasi. Jurnal Teknik Kimia, 1(19): 60-69.

Imsya, A dan R. Palupi. (2008). Pengaruh dosis starter fermentasi cair terhadap kandungan lignin, selulosa dan hemiselulosa pelepah sawit, Jurnal Majalah Ilmiah Sriwijaya, 8(5): 292-297.

Handayani, S., A.E. Harahap dan E. Saleh. (2018). Kandungan fraksi serat silase kulit pisang kepok (Musa paradisiaca) dengan penambahan level dedak dan lama pemeraman yang berbeda. Jurnal Peternakan, 15(1): 1-8.

Koten, B. B. (2010). Perubahan anti nutrisi pada silase buah semu jambu mete sebagai pakan dengan menggunakan berbagai aras tepung gaplek dan lama pemeraman,
Jurnal Buletin Peternakan, 34(2): $82-85$.

Mathius, J.W dan A.P. Sinurat. (2001). Pemanfaatan bahan pakan inkonvensional untuk ternak. Jurnal Wartozoa, 11(2): 20-31.

Maynard, L. A dan J. K. Loosli. (1969). Animal Nutrition. McGraw-Hill, USA.

Meryandini, A., W. Widosari, B. Maranatha, T.C. Sunarti, N. Rachmania dan H. Satria. (2009). Isolasi bakteri selulolitik dan karakterisasi enzimna. Jurnal Makara Sains. 13(1): 33-38.

Meryandini, A., W. Widosari, B. Maranatha, T. C. Sunarti, N. Rachmania dan H. Satria. (2009). Isolasi bakteri selulolitik dan karakterisasi enzimnya. Jurnal Makara Sains. 13(1) : 22-38.

Pramono, A., Kustono, D. T. Widayati, P. P. Putro dan H. Hartadi. 2016. Evaluasi pakan suplemen minyak ikan lemuru dan hidrolisat darah terproteksi berdasarkan kecernaan bahan kering dan kecernaan bahan organik di dalam rumen dan pasca rumen. J. Sains Peternakan. 14(4):36-42.

Prastyawan, R.M., B.I.M. Tampoebolon dan Surono. (2012). Peningkatan kualitas tongkol jagung melalui teknologi amoniasi fermentasi (amofer) terhadap kecernaan bahan kering dan bahan organik serta protein total secara in vitro. Jurnal Animal Agriculture. 1(1): 611621.

Purbajanti, E. D., R. D. Soetrisno, E. Hanudin dan S.P.S. Budhi. (2011). Produksi, kualitas, dan kecernaan in vitro tanaman rumput benggala (panicum maximum) pada lahan salin. Jurnal Buletin Peternakan, 35(1): 30-37. 
Sari, P. D., W.A. Puri dan D. Hanum. (2019). Delignifikasi Bahan Lignoselulosa : Pemanfatan Limbah Pertanian. Qiara Media, Pasuruhan.

Sumadi, Y. Usman dan M. Delima. (2010). Kajian potensi limbah pertanian sebagai pakan ternak ruminansia di Kabupaten Aceh Besar. Jurnal Agripet, 10(2): 4553.

Tilley, J. M. A dan R. A. Terry. (1963). A two stage technique for the in vitro digestion of forage crop. Journal of British Grassland. 18: 104-101.

Tillman, A.D., H. Hartadi, S. Reksohadiprodjo, S. Prawirokusumo dan S. Lebdosoekojo. (1991). Ilmu Makanan Ternak Dasar. UGM Press, Yogyakarta.
Van Soest, P. J. (1994). Nutritional Ecology of the Ruminant. O and B Books Inc Convallis. Ovegon United State of America.

Zain, M. (2007). Optimalisasi penggunaan serat sawit sebagai pakan serat alternatif dengan suplementasi daun ubi kayu dalam ransum ruminansia. Jurnal Indonesian Tropical Animal Agriculture, 32(2): 100-105.

Zakariah, M. A., R. Utomo dan Z. Bachruddin. (2016). Pengaruh inokulasi Lactobacillus plantarum dan Saccharomyces cerevisiae terhadap fermentasi dan kecernaan in vitro silase kulit buah kakao. Jurnal Buletin Peternakan. 40(2): 124-132 